\title{
"El medio ambiente: la empresa más grande del mundo". Reconfiguraciones sociales de la institucionalidad ambiental en Islote, Colombia
}

"The environment is the largest Enterprise in the world". Social Reconfigurations of Environmental

Institutions in Islote, Colombia

"O meio ambiente: a maior empresa do mundo".

Reconfigurações sociais da institucionalidade

ambiental no Islote, Colombia

Andrea Leiva Espitia*

Recibido: 7 de marzo de 2019

Aprobado: 10 de octubre de 2019

Doi: https://www.doi.org/10.12804/revistas.urosario.edu.co/territorios/a.7737

Para citar este artículo:

Leiva Espitia, A. (2020). “El medio ambiente: la empresa más grande del mundo”. Reconfiguraciones sociales de la institucionalidad ambiental en el Islote, Colombia. Territorios, (42-Especial), 1-31. https://www.doi. org/10.12804/revistas.urosario.edu.co/territorios/a.7737

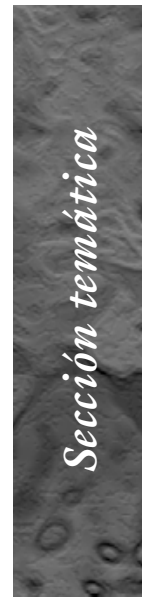

* Docente de la Facultad de Sociologia, Universidad Santo Tomás (Colombia). Correo electrónico: andrea. leiva@usantotomas.edu. co ORCID: https://orcid. org/0000-0002-1240-1536 
Palabras clave

Conservación, Área Maritima Protegida, isla, medio ambiente.

Keywords

Conservation, maritime protected area, island, environment.

Palavras-chave

Conservação, Área Maritima Protegida, Ilha, Meio Ambiente.

\section{tersitorios 42-Especial}

RESUMEN

El objetivo de este artículo es examinar las presencias y reconfiguraciones locales de la institucionalidad ambiental en Islote, una isla del Caribe colombiano. Mediante el trabajo de campo etnográfico que tuvo lugar durante el año 2010, parte del 2011 y visitas posteriores en el 2018, se estudia la organización sociopolítica y el prestigio individual como factores locales que contradicen las expectativas y políticas de Parques Nacionales Naturales de Colombia. Los resultados de la observación participante, entrevistas etnográficas y participación en talleres de las entidades ambientales muestran que la presencia de las instituciones ambientales se separa de su significado local y adquiere otra forma, se convierte en un espacio burocrático de representación externa que es reconfigurado localmente. Inspirada en el concepto de simplificación colonial de Page West (2006), muestro cómo, tanto los isleños como la entidad ambiental, pasan por un proceso de reconfiguración mutua, que genera relaciones, en su mayoría, conflictivas.

\section{ABSTRACT}

The objective of this article is to examine the presence and local reconfigurations of environmental institutions in Islote, an island of the Colombian Caribbean. Through the ethnographic-field work that took place during 2010, part of 2011, and subsequent visits in 2018, I study how socio-political organization and individual prestige are local factors that contradict National Natural Parks of Colombia's expectations and policies. The results of the participant observation, ethnographic interviews, and participation in workshops of environmental entities show that the presence of environmental institutions separates from its local meaning and acquires another form; it becomes a bureaucratic space of external representation locally reconfigured. Inspired by the concept of colonial simplification of Page West (2006), I show how both the islanders and the environmental entity go through a process of mutual simplification that mostly generates conflictive relations.

\section{RESUMO}

O objetivo deste artigo é examinar as presenças e reconfigurações locais da institucionalidade ambiental no Islote, uma ilha do Caribe colombiano. Através do trabalho de campo etnográfico que aconteceu durante o ano 2010, parte do 2011 e visitas posteriores no ano 2018, se estuda a organização sociopolítica e o prestígio individual como fatores locais que contradizem as expectativas e políticas de Parques Nacionais Naturais da Colômbia. Os resultados da observação participante, entrevistas etnográficas e participação em workshops das entidades ambientais, mostra que a presença das instituições ambientais se separa de seu significado localmente e adquire outra forma, se converte-se em um espaço burocrático de representação externa que é reconfigurado localmente. Inspirada no conceito de "simplificação colonial" de Page West (2006) mostra-se como, tanto os ilhéus quanto a entidade ambiental, passam por um processo de simplificação mútua gerando relações, em sua maioria conflitivas. 


\section{Introducción}

La discusión académica sobre las islas frente al cambio climático generó una corriente creciente llamada giro oceánico -oceanic turn- (DeLoughrey, 2018). Entre las preocupaciones de este enfoque ecológico y cultural está la de entender el papel de las islas como territorios más vulnerables que otros (Kelman, 2006; 2010), debido a su exposición a la erosión costera, los aumentos en el nivel del mar, la presión demográfica y el turismo desmedido, entre otros factores socioambientales. Según DeLoughrey (2018), la idea de aislamiento de las islas ha estado atravesada por la naturalización del mar, perspectiva desde la cual se asume que el océano es un espacio vital material que evoca los flujos imperiales, la modernidad y la globalización. Esta visión generalizada abstrae al océano de una visión histórica y borra su importancia como moldeador del pasado y del cambio climático (DeLoughrey, 2018). El giro oceánico, permite replantear la visión naturalista del mar, para generar un nuevo imaginario en el que este es entendido como la confluencia de "complejas trayectorias de migración, diáspora, flujos globales del imperio, capital y cultura" (DeLoughrey, 2018, p. 186).

Dentro de este giro oceánico cambia también la percepción de las islas: pasan de ser pensadas como lugares ideales, utópicos, tal y como lo retratan las visiones literarias y filosóficas, ${ }^{1}$ a cuestionar la idea generalizada de aislamiento (islandness). Suponer que existe una condición distintiva de aislamiento sería, como lo muestran Warrington y Milne (2018), imponer características biológicas de estos ecosistemas a la vida social. El peligro de estas perspectivas, reiteran los autores, es que generalizan sobre la vida de los insulares y marginalizan sus formas de interacción con otros agentes. El giro oceánico busca reconocer el papel activo de las poblaciones insulares como motores históricos, políticos, moldeados y moldeadores de las transformaciones de estos espacios.

Así concebidas, las islas se pueden entender como espacios producidos socialmente, es decir, apropiados, controlados, entendidos y representados en el contexto de nuevos materiales y sistemas de representación relacionados con ese espacio (West, 2006, p. 7). El mar, las zonas costeras, los navegantes, los turistas, las instituciones y las poblaciones locales participan en este proceso de producción. Siguiendo a West (2006), las imágenes y discursos externos y las prácticas y relaciones de sus pobladores con el entorno transforman estos espacios en lugares, son objetos creados y sustentados en medio de relaciones sociales cambiantes.

Uno de los discursos que influye en la concepción de los espacios marítimos y costeros es el de la conservación. En diferentes partes del mundo, sometidas con mayor fuerza a presiones del cambio climático y conflictos socioambientales, surgen distintas políticas que ponen en evidencia
Algunos estudios que abordan las diferentes visiones sobre las islas son Drouin y Foucault (1997) y Royle y Brinklow (2018).

“EL MEDIO AMBIENTE: LA EMPRESA MÁS GRANDE DEL MUNDO"

territarios 42-Especial 
${ }^{2}$ Por giro participativo los autores expresan el cambio de la politica de conservación restrictiva y proteccionista a una aproximación donde la población se vuelve actor de participación (Thing, Jones \& Birdsall Jones, 2017).

${ }^{3}$ Es decir, aquella ideología que, usando el mercado basado en estrategias de desarrollo neoliberales como la conservación, disfraza de diferentes maneras el acceso al poder (West, 2006, p. 36).

\section{territorias 42-Especial}

el choque del "conocimiento experto" y el local (Agrawal, 1995; Goldman, 2003). Desde algunas perspectivas, estas confrontaciones se analizan como un conflicto entre el "conocimiento experto" de los funcionarios ambientales y el "conocimiento local" de las poblaciones. Para el caso de Tanzania, Goldman (2003) ilustra los alcances y contradicciones que surgen en la aplicación de la política de conservación basada en comunidades Community Based Conservation ( $\mathrm{CBC}$ ) que es popular en África, pero margina el conocimiento socioecológico local.

Otros estudios, como el de Holmes (2007), analizan la relación entre la resistencia y las políticas de conservación. $\mathrm{Al}$ retomar la perspectiva de Scott (2003) sobre las formas no abiertas, sutiles y solapadas de resistencia cotidiana, Holmes (2007) explora la relación entre las "comunidades locales" y los funcionarios que propenden por la conservación. Su objetivo es mostrar cómo las entidades que administran la biodiversidad ignoran estos lenguajes ocultos y entorpecen la aplicación de las políticas. Así, refuerzan el descontento de las personas y fomentan conflictos con el proceso de conservación. Por su parte, Thing, Jones y Birdsall Jones (2017) critican lo que ellos llaman "el giro participativo" 2 en las políticas de conservación mediante un estudio localizado en el Parque Natural Bardia (Nepal). Esta etnografía crítica plantea que el cambio de paradigma conservacionista en lugar de invertir el enfoque tradicional, que somete a los habitantes a las medidas restrictivas, lo reforzó. La consecuencia de este proceso fue la marginalización cada vez mayor de la población local.

Paige West (2006) va más allá del conflicto bipolar entre instituciones y analiza cómo estos dos actores entienden la relación entre medio ambiente y sociedad. Su etnografía, llevada a cabo en una montaña protegida donde vive la población Gimi en Nueva Guinea, busca conectar las escalas locales, nacionales, globales y transnacionales examinando las producciones discursivas y materiales que surgen del paradigma de la conservación como motor del desarrollo. ${ }^{3}$ Uno de los aspectos llamativos de su argumento es que invita a repensar la relación entre los diferentes actores: habitantes, ONG, propietarios de terrenos e instituciones. El autor sobrepasa la lógica dualista de la relación entre "comunidad local" y otros actores externos mostrando cómo estos hacen parte de una configuración compleja en constante negociación (West, 2006, p. 36).

La perspectiva de West (2006) permite entender que la articulación entre los actores externos y locales en términos de la conservación crea relaciones recíprocas e intersubjetivas; juntas producen lugares con intereses y significados distintos. Se puede decir que estos espacios son construidos ante los ojos externos por las prácticas y discursos burocráticos.

Los habitantes locales también tienen sus propias formas de simplificación de 
los funcionarios y las instituciones, que en este artículo llamo reconfiguraciones de la institucionalidad, pues transforman la definición y el propósito original de las entidades otorgándoles un nuevo significado. En este caso, el medio ambiente es definido como una "empresa" que abarca tanto ONG como organizaciones del gobierno, principalmente el Parque Nacional Natural Corales del Rosario y San Bernardo (PNNCRSB). Aquí se pretende mostrar cómo los habitantes del Islote, en el Caribe colombiano, reinterpretan la figura ambiental, separándola de su significado y le otorgan otra presencia: un espacio de representación burocratizada y externa a la percepción y manejo local del entorno.

\section{La isla y la conservación}

En Colombia, una de las áreas insulares objeto de protección especial por parte del Estado es el PNNCRSB. ${ }^{4}$ Este fue delimitado por primera vez en 1977 y redefinido en 1996, año en el que se incorporó el Archipiélago de San Bernardo a su área (figural 1). Ocupa 120000 hectáreas de área sumergida, las islas e islotes que ocupan la franja litoral entre Cartagena y el municipio de San Onofre en Sucre (UAESPNN, 2006b).

Aunque el PNNCRSB solo ejerce jurisdicción sobre algunas islas y el área marítima protegida (AMP), requiere necesariamente de la interacción con los habitantes del archipiélago para incidir en las políticas de conservación. Una de las comunidades es la de Islote, caracterizada por la pequeñez, tanto en extensión (1 hectárea $)^{5}$ como en población $\left(600^{6}\right.$ habitantes). Como consecuencia de su alta densidad demográfica, en el contexto turístico y no sin cierto exotismo, se le concibe como "la isla más densamente poblada del mundo" (figura 2). Allí no existen playas ni terrenos cultivables, tampoco bosques de manglar ni cuerpos de agua dulce, como sí ocurre en las islas vecinas y otras del Caribe.

Esta isla está alejada de su centro administrativo. En el ordenamiento territorial regional, aparece como corregimiento ${ }^{7} \mathrm{del}$ Distrito Turístico y Cultural de Cartagena de Indias, ciudad capital del departamento de Bolívar, que queda a $60 \mathrm{~km}^{8}$ de Islote.

En el Islote se concentra el $95 \%$ de la población del Archipiélago de San Bernardo (Cano \& Valderrama, 1996) y por esta razón el PNNCRSB la concibe como un sector de alta incidencia en las dinámicas ecológicas de la zona protegida. En otras zonas del parque natural, como el archipiélago de Rosario, ubicado en las inmediaciones de la ciudad de Cartagena, las políticas de conservación han permeado progresivamente el discurso de los habitantes (Durán, 2009). Islote es el punto neurálgico de la relación entre la institucionalidad y la gente. El PNNCRSB se presenta de diferentes maneras en la isla: mediante sus funcionarios individualmente, por medio de correspondencia que llega desde Cartagena y también presencia
${ }^{4}$ La entidad que cobija la administración de este parque natural se llama Unidad Administrativa de Parques Nacionales Naturales y "es una dependencia pública de carácter operativa, técnica y ejecutor, con autonomía administrativa y financiera, encargada por mandato legal de la gestión del Sistema de Parques Nacionales Naturales, según el mandato de la Ley 99 de 1993, el Decreto 622 de 1977, el Decreto de Ley 2811 de 1974, y el Decreto 216 de 2003. Asi mismo, su estructura está integrada a nivel nacional por una Dirección General, dos Subdirecciones (Técnica y AdministrativaFinanciera), por seis Direcciones Territoriales a nivel regional (Costa Atlántica, Noroccidental, Suroccidental, Norandina, Surandina y Amazonía Orinoquía) y por las áreas del sistema adscritas a cada una de las Direcciones Territoriales; agrupa funcionarios y contratistas, los cuales se han especializado en diferentes temas relacionados con la gestión de la conservación, con miras a cumplir con la visión y misión de la Unidad" (UAESPNN, 2006b).

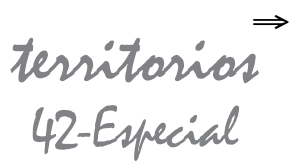


$\Longleftarrow$

${ }^{5}$ Para que el lector o lectora se haga una idea, el islote tiene un área equivalente al tamaño de una cancha de fútbol.

${ }^{6}$ Censo personal becho en junio de 2010.

7 Según el Departamento Nacional de Estadistica -DANE- (s.f.), un corregimiento es una subdivisión de un departamento que incluye un núcleo de población (p. 2).

${ }^{8}$ Dato extraido de Google Maps. Dependiendo de los vientos y las corrientes marinas, entre Cartagena y el islote un trayecto dura un máximo de dos horas.

\section{territarios \\ 42-Especial}

Figura 1. Parque Natural Corales del Rosario y San Bernardo

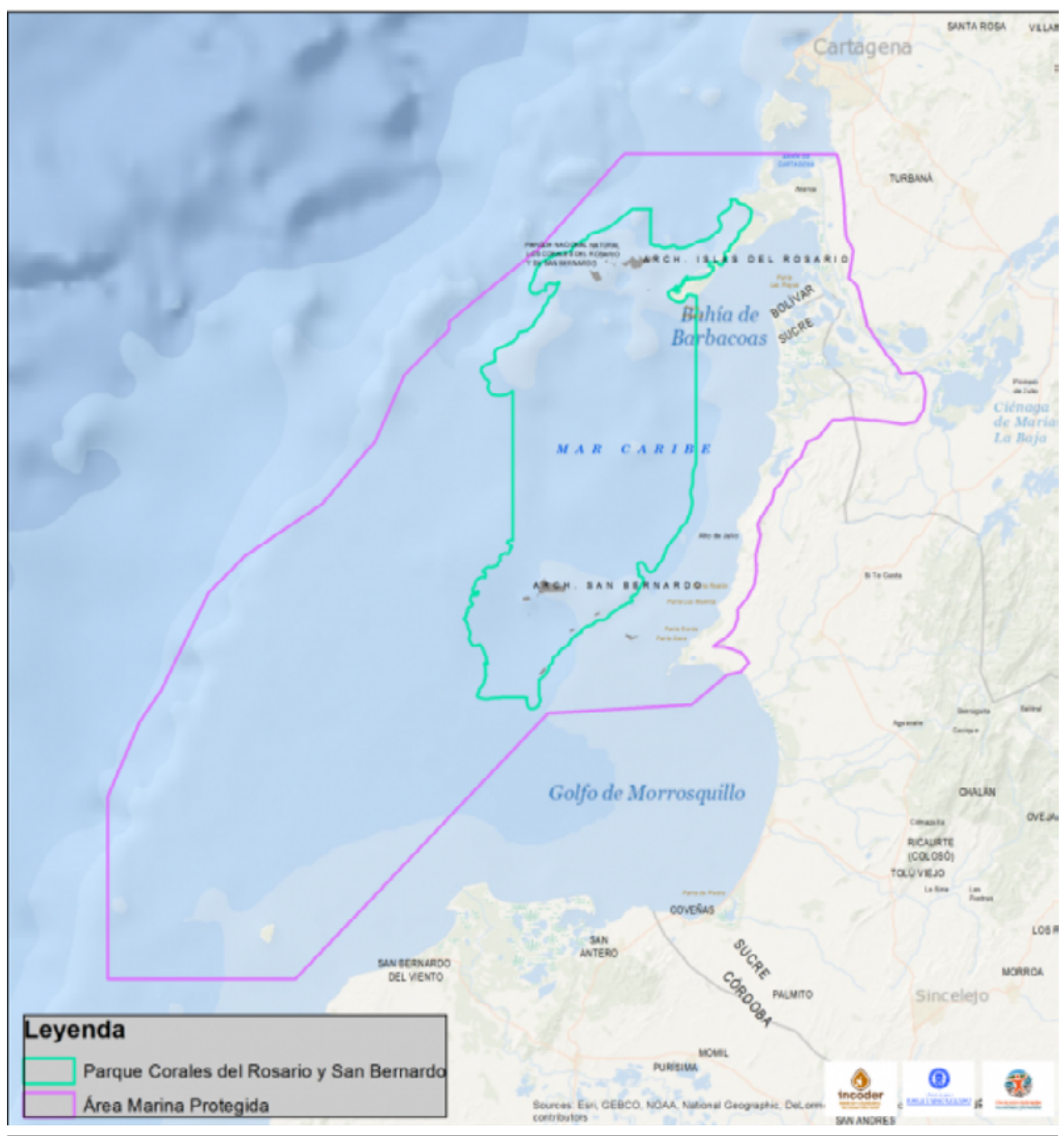

Fuente: Plan de Manejo (UAESPNN, 2006a). 


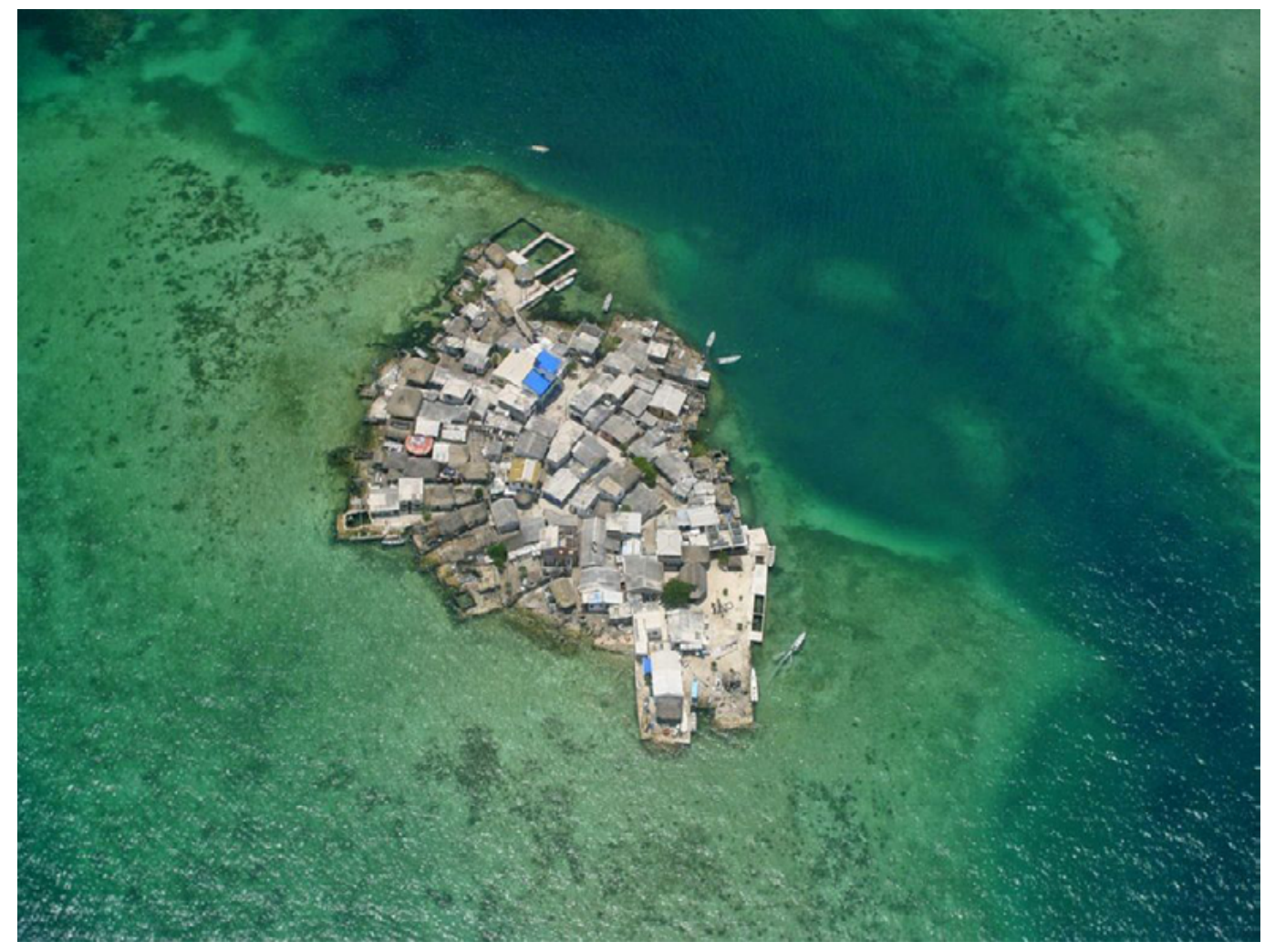

Fuente: http://www.hotelpuntanorte.com/index.php/programa

colectiva con grupos que llegan a hacer talleres con los pescadores. Todas estas imágenes son designadas por los isleños bajo la etiqueta de "Medio Ambiente". Pero, ¿cuáles son los discursos y las prácticas "locales" en relación con el medio ambiente y la conservación? ¿Cómo asumen los isleños su entorno y las presiones de ser sujetos ambientalistas?

Según Escobar (1998), en el caso colombiano, existe una asimetría entre los discursos institucionales sobre la biodiversidad y las formas locales en las que estos son asumidos. Este desequilibrio está ligado a las construcciones propias sobre la naturaleza por parte de las poblaciones (Escobar, 1998, p. 55). Más allá de esto, el presente texto parte de la necesidad de analizar otros factores que inciden en el conflicto como el encuentro y desencuentro de las poblaciones con las entidades encargadas de la conservación. territarios 42-Especial 
${ }^{9}$ Este articulo es producto del estudio realizado entre 2010 y 2016 en el islote, en el marco de la tesis doctoral: Yo me la paso de isla en isla: formas de habitar e interacciones sociales en el Islote, Bolívar-Colombia, École Pratique des Hautes Études, Paris, 2016.

${ }^{10}$ El PNNCRSB se considera "un área protegida de carácter submarino, $y$ de acuerdo a sus caracteristicas naturales es considerada como ecosistema especial a nivel mundial, comprende la fracción más desarrollada de corales en la franja caribe continental colombiana. Debido a la alta variedad biológica y a sus cualidades escénicas, el Parque se ha constituido en uno de los principales atractivos turisticos del caribe colombiano $y$ en especial de la ciudad de Cartagena de Indias DT.” (UAESPNN, 2006a, p. 11). El parque hace parte del SINAP o Sistema Nacional de Áreas Protegidas, conformado por varias entidades, dentro de las cuales la Unidad de Parques Naturales Nacionales de Colombia tiene a su cargo la administración de las mismas, véase: http://www. parquesnacionales.gov.co/ portal/es/sistema-nacionalde-areas-protegidas-sinap/

\section{territarios 42-Especial}

Por ejemplo, el choque entre las formas propias de organización sociopolítica y las políticas institucionales. Retomando la perspectiva de West (2006), aquí se arguye que para analizar los encuentros y desencuentros socioambientales locales, es necesario entender no solo las configuraciones sociopolíticas de las poblaciones, sino la forma en la que los locales interpretan, negocian y redefinen la presencia institucional.

Con base en la etnografía realizada en diferentes estancias en Islote, ${ }^{9}$ el objetivo de este artículo es analizar la interacción y la reconfiguración de la imagen que tienen sus habitantes sobre el PNNCRSB. Para ello, se toman como eje las dinámicas sociopolíticas y los saberes locales como la pesca y economías crecientes como el turismo, que ponen en evidencia la desigualdad, el prestigio individual y la reputación como factores que impiden el desarrollo de una política comunitaria, organizada y participativa de conservación.

El argumento se divide en tres partes. La primera tiene la intención de mostrar el choque entre las formas de organización sociopolítica locales y las expectativas de participación de la institución ambiental frente a los escenarios de conservación. La segunda, evidenciar las formas o saberes que los isleños tienen sobre la noción de medio ambiente y naturaleza, a partir de la figura histórica de los cazadores de tortuga y del turismo como prácticas que se confrontan a la conservación esperada por las instituciones ambientales. La tercera muestra los procesos de reconfiguración local de la figura institucional bajo la etiqueta de medio ambiente.

\section{La intermitencia de lo social y lo político frente a la expectativa de manejo del PNNCRSB: visiones encontradas}

A nivel nacional, la entidad Parques Nacionales Naturales de Colombia tiene dentro de sus herramientas de planeación y gestión documentos llamados planes de manejo cuyo propósito es "orientar la gestión de las Área Protegidas ${ }^{10}$ permitiendo alcanzar sus objetivos de conservación" (UASPNN, 2006, p. 9). Dentro de las dinámicas que propone la institución para el manejo del parque están la educación ambiental, el control de uso de los recursos naturales y un componente que es de especial importancia dentro del argumento de este texto, que es la propuesta de una "Participación Social para la Conservación”. Esta incluye varios actores como las comunidades nativas (UASPNN, 2006, p. 11), de quienes se espera que coadyuven en la conservación mediante proyectos de ecoturismo y la “conformación de grupos organizativos comunitarios" que hacen parte de espacios llamados comités consultivos para, entre otras cosas, concertar y solucionar conflictos relacionados con el manejo del parque natural. La participación social así entendida proyecta sobre los pobladores locales la imagen de una comunidad 
susceptible de, por un lado, organizarse y armonizarse para el diálogo y, por el otro, ser influenciada para transformar su idea propia de conservación.

Según el plan de manejo vigente desde el año 2006, la política de participación social, que hace parte de un plan general llamado "Parques con la Gente", ha "conllevado (sic) a un cambio de actitud hacia el manejo de los recursos naturales logrando consensos para la disminución de conflictos" (UAESPNN, 2006, p. 91). Las expectativas organizativas de la institución, así como las supuestas transformaciones en la concepción y uso del entorno por parte de los pobladores de Islote contradicen la realidad local. Por un lado, las formas de organización sociopolítica de los isleños no han permitido que los espacios de consulta ni aquellos de participación formen una comunidad organizada y coherente con ambiciones compartidas de preservación. Por el otro, las relaciones de los habitantes con los funcionarios se caracterizan por la ambivalencia entre lo que Scott (2003) llamaría las formas cotidianas de resistencia. Estas operan mediante el rumor y la indiferencia, la aceptación implícita donde median, entre otras cosas, vínculos de amistad y camaradería, y la reinterpretación del discurso de conservación por parte de los habitantes. Estas dos características corresponden a las formas propias del ethos isleño y hacen parte de las dinámicas socioespaciales locales.

\section{Las escalas y los discursos de la comunidad}

Las definiciones clásicas de comunidad desde las ciencias sociales la entienden como "una unión metafísica de cuerpos y de sangre [con] un derecho propio con respecto a las voluntades de sus miembros" (Tönnies, 1947). También es usada para connotar la escala en la que la gente interactúa y se reconoce sin necesidad de una interacción personal, como lo demuestra Anderson (1993) para el caso de la nación. La escuela de Chicago se aproxima al concepto para definir el vecindario en el contexto urbano (Gregory, et al., 2009, p. 103). Sin embargo, la comunidad adquiere significados, escalas y formas tanto prácticas como discursivas distintas de acuerdo con el contexto en el que se analice.

En el caso particular de las islas, espacios exiguos, estudios como el de Wilson (2004) ilustran la correspondencia entre la pertenencia a un lugar cercado por el mar y la pertenencia a "una gran familia" que, en algunos casos, se asume como una comunidad. En Islote, la comunidad designa el vínculo que sus habitantes tienen por el hecho de pertenecer a un lugar donde las relaciones de parentesco y de convivencia son especialmente estrechas.

El uso político de la categoría "comunidad negra" se ha extendido entre los isleños debido a la necesidad de defender su derecho a la tenencia de las islas ante las instancias del gobierno local. Teniendo en territorios 42-Especial 
${ }^{11}$ El Código Fiscal de 1873 $y$ de 1912 disponen en su artículo 45 [literal b] que se reputan baldios, $y$, por consiguiente, de propiedad nacional "las islas de uno $y$ otro mar pertenecientes al Estado”, que no estén ocupadas por poblaciones organizadas o apropiadas por particulares en virtud de un título traslaticio de dominio (justo título).

12 Procesos similares son analizados por Hoffmann (2007) y Losonczy (1997).

${ }_{13}$ Artículo 2, capitulo 6 de la Ley 70 de 1993.

${ }^{14}$ Parte de esta información etnográfica se extrae de la tesis doctoral (Leiva Espitia, 2016).

\section{territarias 42-Especial}

cuenta que estos terrenos son considerados por el Estado como "baldíos"11 reservados a la nación, los isleños consideran que su derecho de propiedad sobre el islote y las islas aledañas se adquiere por haberlo construido, ${ }^{12}$ de acuerdo con lo estipulado en la Ley 70 de 1993, que otorga derechos territoriales a ciertas comunidades negras. Para defenderlo, desde el año 2011 un grupo de lugareños formó un consejo comunitario, en el marco de la Ley 70 de 1993 o Ley de Comunidades Negras. Esta les permite reclamar un territorio colectivo si cumplen varios requisitos, entre ellos demostrar la ocupación "histórica y ancestral" ${ }^{13}$ del asentamiento. El uso de la noción de comunidad entre los habitantes de Islote, supone entonces un sentido de pertenencia colectiva a un territorio compartido por personas con lazos de parentesco y convivencia estrechos, y por el otro, es consecuencia de eventos recientes que se enmarcan en las políticas multiculturales surgidas en el marco de la Constitución de 1991.

Así vista, la comunidad evoca un grupo organizado sobre una base de relaciones igualitarias y visiones compartidas. No obstante, como afirma Wilson (2004) para el caso de la isla de Providencia, este tipo de principios en los que, en el caso de las islas, se subsume la pertenencia de sus habitantes a "una gran familia" o una comunidad, es una característica propia de los grupos que son abiertamente desiguales. La idea de unidad de los isleños se usa como una herramienta retórica frente a los turistas y a las presencias externas para generar una imagen de unidad, pero en su interior esconde profundas desigualdades sociales (Wilson, 2004, p. 14). El análisis de la configuración socioespacial de Islote sirve para comprender esta desigualdad latente y analizar cómo la organización que se desprende de una tal configuración se confronta al ideal comunitario, participativo y organizativo de las instituciones ambientales.

\section{La correspondencia entre el espacio y el prestigio social y político ${ }^{14}$}

La configuración socioespacial isleña se caracteriza por la presencia de diferentes figuras o cabezas que sobresalen en coyunturas específicas y por razones determinadas. Las escalas espaciales de la isla (tabla 1) se pueden entender como diferentes segmentos residenciales: la casa, el calce, el barrio y la isla.

Tabla 1. Escalas y relaciones de los grupos residenciales

\begin{tabular}{|l|l|l|}
\hline \multicolumn{1}{|c|}{ Espacio } & Grupo residencial & \multicolumn{1}{c|}{ Vínculo } \\
\hline Casa/patio & Familia & $\begin{array}{l}\text { Materno (tía } \\
\text { o madre) }\end{array}$ \\
\hline Calce & $\begin{array}{l}\text { Grupo de } \\
\text { hermanos }\end{array}$ & $\begin{array}{l}\text { Paterno (tío } \\
\text { o padre) }\end{array}$ \\
\hline Barrio & Parentela & $\begin{array}{l}\text { Progenitor- } \\
\text { fundador } \\
\text { (transmite } \\
\text { el apellido } \\
\text { dominante) }\end{array}$ \\
\hline
\end{tabular}


La casa es la escala mínima del espacio social que constituye a Islote. Allí la "tía", figura materna alrededor de quien confluyen los descendientes de esta con uno o varios progenitores, es la autoridad central. Las casas son de distintos tamaños, formas, colores y distribución. El patrón que se identifica es la presencia de una familia, grupo residencial que puede estar compuesto por la abuela materna y distintos hijos e hijas solteras, familias monoparentales y nucleares. El calce es el terreno ocupado por varias casas, cada una de las cuales fue construida por el descendiente de una pareja de progenitores o por un mismo progenitor hombre con diferentes esposas. Es entonces el terreno del grupo de hermanos. El barrio es la confluencia de calces en el cual conviven un grupo de parientes consanguíneos como primos, tíos y tías, y parientes de alianza como cuñados y cuñadas. Es el lugar de la parentela y se identifica por el apellido del fundador del barrio, progenitor de la mayor parte de los descendientes.

Cada barrio puede tener una o varias cabezas reconocidas como figuras importantes de la isla: puede ser una "tía" o una mujer que reviste una cierta autoridad o un hombre que posee el terreno más amplio o que es respetado por su edad y trayectoria en la isla. Pero estas figuras fluctúan constantemente: el prestigio y la prosperidad económica marcan los ciclos de estas cabezas, especialmente para el caso de los hombres. Mientras que la "tía" tiene una cierta estabilidad como una imagen respetable, el hombre que cae en desgracia económica puede perder su prestigio y, por ende, su capacidad de ser autoridad. Estas fluctuaciones se caracterizan porque en determinados momentos florecen sectores opuestos o facciones familiares que se enfrentan por obtener una cierta representación política en instancias como la junta de acción comunal. ${ }^{15}$

\section{La isla dividida: envidia e intermitencia política}

La organización política se caracteriza por la emergencia esporádica de familias e individuos que entran en pugna por el prestigio. Una ganancia eventual permite construir una casa de material, ampliarla, modificar el suelo, hacer arreglos a los patios o mejorar los muros de contención. De forma paralela, la reputación se manifiesta en la posibilidad de hacer fiestas, invitar a los pares a la bebida, usar joyas de oro y poder moverse constantemente entre Islote y otras ciudades. El estatus se asocia también con el hecho de tener el monopolio, así sea temporal, de negocios como la venta de pescado o abrir una tienda de víveres, una cantina y una gallera (Leiva Espitia, 2016).

La llegada de un nuevo inspector, que es la figura policiva, reconfigura las alianzas y conflictos entre familias. Históricamente, diversos personajes llegados como representación del gobierno departamental marcaron de alguna forma las relaciones internas. En los relatos de los mayores es
15 La Junta de Acción Comunal es una figura asociativa que se creó en 1930 y reune a los habitantes de un mismo entorno como los barrios o corregimientos. 
${ }^{16}$ Surgió en el mismo periodo de la influencia paramilitar en el Golfo de Morrosquillo. Los paramilitares intentaron permear la policía cívica de Islote, proponiéndoles a los isleños que les entregaran a las personas que fueran atrapadas consumiendo drogas o robando, pero los isleños se negaron pues sabian que los paramilitares iban a bacerle daño a sus familiares. Fernando afirma: "a ese juego ya no jugábamos nosotros”.

17 Una babitación creada por los isleños para retener a las personas durante un tiempo indeterminado.

\section{territarias 42-Especial}

recurrente la historia de un viejo profesor llamado Ciro que se evoca con algo de nostalgia por los buenos tiempos: él era el médico, el consejero, solucionaba conflictos entre familias, enseñaba a leer a los viejos y organizó la primera junta de acción comunal. Por eso, las generaciones entre los sesenta y ochenta años lo recuerdan con nostalgia.

Entre el final de los noventa y principios del 2000, se recuerda a un inspector que llegó a la isla y unió a una parte de la población en torno a preocupaciones comunes: formó una policía cívica ${ }^{16}$ que servía para controlar los conflictos ligados a la bebida, el consumo de drogas o vicio, las peleas domésticas y la hora de dormir de los niños. Ese grupo de vigilancia estaba compuesto por varios isleños que simpatizaban con el inspector de turno quien hizo las gestiones para que el grupo fuera reconocido jurídicamente en la alcaldía de Cartagena. Sus funciones eran controlar cualquier brote de violencia y, sobre todo, las peleas entre jóvenes y entre las mujeres, como lo indica Fernando, un isleño que hizo parte de la misma:

\section{A.L.: Y, ¿̨cuáles eran las funciones?}

F: ... de controlar el pueblo cuando había pelea, los que se portaban muy... ¿ Cómo es que llamamos nosotros eso? ¿Muy impertinentes? Los cogíamos y los encerrábamos.

$$
\text { A.L.: } \mathrm{Y} \text {, ¿̨ónde? }
$$

F: Teníamos un calabozo ${ }^{17}$ que llamábamos amansaguapos... éramos patrullas, cada patrulla tenía cinco [personas] y tenía un comandante. Yo era presidente, primero lo cogió otra persona y luego se lo quitaron... luego yo entré a ser presidente... Yo fui el que se aguantó más con la cívica. Cuando yo me salí ya todos se salieron, dijeron que no iban a trabajar con otro... cogíamos mucha gente aquí que venía con vicio, con mucho vicio pa' vender a los pelaos.

A.L.: Pero encerraban a la persona y, ¿cuánto tiempo la dejaban en el calabozo?

F: ... un día... los problemas si un marido le pegaba a una mujer... sí claro, arreglábamos todos esos problemas, también varias mujeres peleando un solo hombre. Hicimos convenios con los padres de familia, tomábamos los datos, pero con la comunidad, entonces nos reuníamos. Tomábamos las decisiones juntos y los pelaos andaban muy rectecitos [juiciosos] porque no se ponían a estar en la calle. Ahora es que ya los veo otra vez... en las fiestas los pelaos solo podían estar hasta las seis hasta la siete-ocho. Y en las fiestas entrábamos a trabajar con dos patrullas, estábamos doce personas.

Las labores de la policía cívica eran, entonces, castigar y perseguir a quienes incurrían en delitos asociados a las drogas (vicio) y otros problemas menores. Incluso, construyeron un calabozo o prisión, el amansaguaposy, según Fernando, tenían éxito imponiendo medidas de autoridad. 
En la isla se recuerda esta figura como "gente que hacia cumpliv" las normas establecidas. Las fiestas y el consumo de alcohol y de drogas estaban bajo constante vigilancia. El inspector de la época logró congregar a la gente, en cierta medida, porque llegó con su mujer y su hijo a vivir allí y permanecía más tiempo en la isla que otros inspectores. Luego, el mando de la policía cívica pasaría a manos de otra persona opuesta a los aliados del otrora inspector, por esa razón llegó a su fin.

El cambio de corregidor después de unos años de funcionamiento de esta policía, causó una recomposición de las relaciones políticas e interfamiliares. $\mathrm{La}$ presencia del representante político anterior delineó los contornos de las facciones. Estas fricciones originaron la imagen de una isla dividida en dos sectores familiares que puede ilustrarse incluso en términos espaciales.

Estas pugnas y relaciones de fuerza entre individuos y sectores tienen como fondo discursivo el argumento de la envidia. Localmente, la envidia se refiere a una acción que ejerce una persona sobre otra para cometer algún perjuicio como llevarla a la pobreza, romper sus relaciones familiares o matrimoniales o evitar que prospere en algún negocio personal. En un contexto exiguo como Islote, donde el acceso a los recursos físicos, sociales y económicos es limitado, la envidia se puede interpretar como una acción que impide la acumulación permanente de los recursos por parte de una sola persona o familia. También influye en las relaciones sociopolíticas internas: si existen facciones políticas opuestas, una acusará a la otra de tener envidia y de ejercer acciones de brujería o expandir rumores para acabar con las posibilidades de ascender social, económicamente o en la capacidad de liderazgo de la facción contraria.

Varios estudios han propuesto aproximaciones sobre la noción de envidia en contextos locales y diversos. El trabajo de Foster (1972) entre poblaciones rurales de México, la define como el hecho de desear algo que el otro posee. Según su perspectiva, es un mecanismo para regular los intercambios entre una sociedad igualitaria. Como la riqueza acumulada y el prestigio son fuente de desazón para quien los tiene, los actos agresivos como la brujería obligan al individuo a distribuir su riqueza controlando la acumulación. Esta idea resulta pertinente para analizar un espacio exiguo como Islote; Foster (1965) propone la “imagen del bien limitado [definida como] amplias áreas de conducta (...) moldeadas de tal modo que sugieren que los campesinos ven sus universos social, económico y natural como uno en el que todas las cosas deseadas de la vida (...) existen en cantidad finita" (p. 87). Esta imagen genera una disputa en la que "un individuo o una familia, solo puede mejorar su posición a expensas de otros" (Foster, 1965, p. 89).

Bougerol (2008) muestra que la "persecución mágica" mediante la brujería se atribuye a la envidia en la isla de territarias 42-Especial 


\section{tersitorias 42-Especial} 14
Guadalupe. Su perspectiva no se interesa en esta noción como dispositivo de regulación social, económica ni simbólica como propone Foster (1972), sino como un "sentimiento" en la interacción que define las formas de la relación entre individuos. Una perspectiva alternativa a las anteriores es la de Ariel de Vidas (2007) en su trabajo con los teenek en México. Más allá de la configuración socioeconómica de la envidia como una forma de control de la acumulación individual, la autora plantea una aproximación simbólica y sociocultural. Propone que este es un sentimiento compartido que articula socialmente símbolos y expectativas en cuanto al comportamiento social. Su apuesta es la de entender la envidia como una forma cultural que, al ramificarse, contribuye a demarcar los contornos de una "comunidad" (Ariel de Vidas, 2007, pp. 215-216).

En Islote, la envidia requiere ser analizada desde el lente de la condición socioespacial, como un dispositivo para incluir o excluir parientes en un lugar donde las relaciones cara a cara son la constante cotidiana. Este mecanismo es una de las formas de entender la intermitencia de las figuras de autoridad y prestigio. El inspector, como instancia política designada por el gobierno local de Cartagena, tiene una representación legal, pero esto no significa que tenga legitimidad absoluta.

Si se contrastan estos tipos de relaciones: intermitentes, coyunturales y cambiantes con el propósito de Participación
Social del PNNCRSB como política de conservación y manejo ambiental, se reducen las posibilidades de la institución de incidir y organizar a la población en torno a un propósito colectivo. Los resultados evocados en el plan de manejo reposan en el terreno de la retórica frente a la realidad práctica y discursiva de los pobladores locales. No obstante, estos últimos reaccionan frente a las políticas ambientales con mecanismos de aceptación y rechazo que ponen en evidencia no solo el carácter variable y fragmentado de sus formas de organización social y política, sino la ambivalencia de las presencias y las prácticas de los funcionarios estatales.

\section{El prestigio social vs. la participación social}

Lo que subyace tras el análisis de la organización sociopolítica de Islote es el prestigio sociotemporal como motor de las relaciones sociales y del estatus de ciertas cabezas que sobresalen por distintos factores, entre ellos, el de la prosperidad económica. Esta característica de la estructura social se puede acotar en la categoría de reputación, entendida como

la muestra de respeto de otra gente por él y una preocupación por el respeto, por el buen nombre (...) la reputación estipula los requerimientos mínimos para la madurez masculina y el respeto. Con una buena reputación, un hombre puede tener su lugar en la sociedad y puede fortalecerlo 
para crear una posición distintiva (Wilson, 2004, pp. 177-178).

Este concepto colinda con el de prestigio: "el resultado de las valoraciones humanas acerca de aquellas situaciones en las que nos encontramos en todo momento, es una valoración más elevada de un individuo o de un fenómeno colectivo" (Boucek, 1995). El prestigio, tiene dos dimensiones que según Boucek (1995) son, en primer lugar, orgánicas: la edad, el sexo, el comportamiento, la contextura física, y psíquicas: el conocimiento, la sabiduría y la educación. En segundo lugar, están las sociales que se expresan en aspectos como la reputación familiar. En el caso de Islote, una de las dimensiones de este prestigio es la de ser un "buen pescador", aspecto que tiene efectos sociales notorios entre sus habitantes y en la interacción con la institucionalidad ambiental.

El discurso sobre la reputación del buen pescador se basa especialmente en la especialización de casi toda la población de pescadores locales en el buceo o pesca de fondo, aquella que se practica en los arrecifes o "bajos" que circundan el archipiélago. Esto, en contraste con otras poblaciones cercanas como Berrugas, donde la pesca a mar abierto o pelágica es la que prevalece. Frente a otros grupos de pescadores, el hecho de ser buzos les otorga un cierto prestigio colectivo. Este factor de reputación tiene un fundamento histórico pues fueron los integrantes de una generación de isleños que nació en la primera mitad del siglo Xx y se dedicaron durante buena parte del mismo siglo a la cacería de tortugas.

\section{Los cazadores de tortugas: la dimensión "orgánica” e histórica del prestigio social}

Figura 3. Los cazadores legendarios de tortuga en Islote, 1970

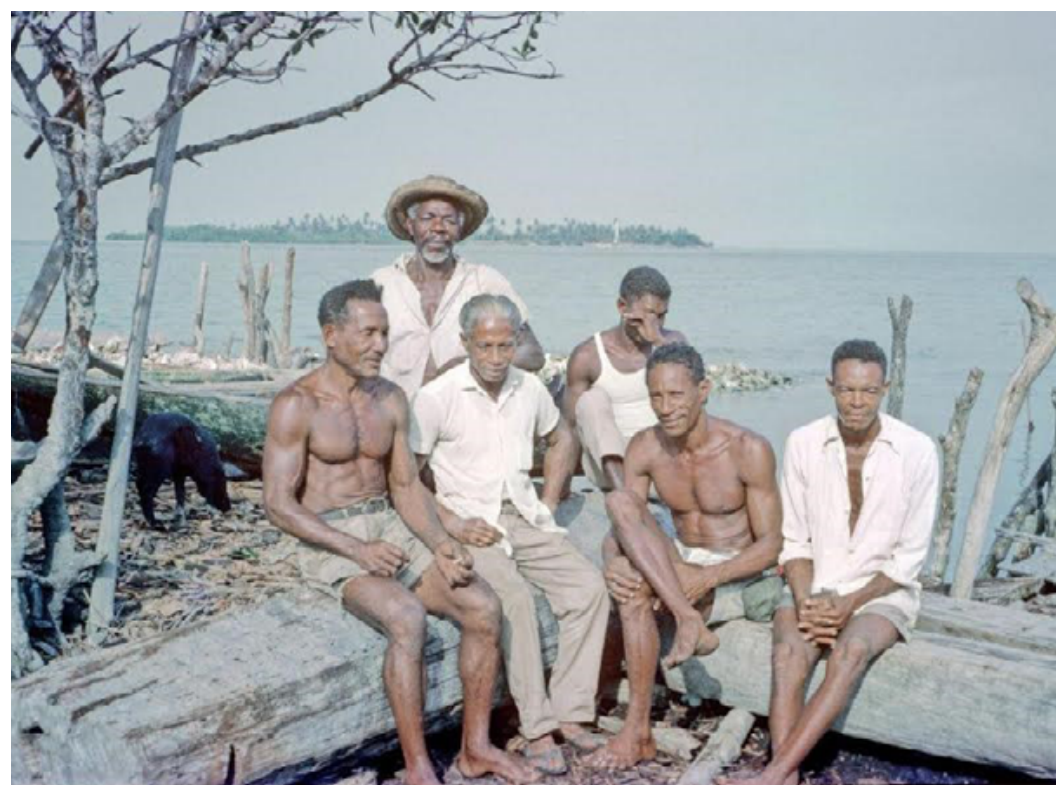

Fuente: Archivo personal Stanley Heckadon.

La figura 3 muestra a la generación reconocida como los hombres de prestigio de Islote en la década de 1970. Según Heckadon, antropólogo que hizo trabajo de campo en la época, su reputación se basaba en ser buenos buzos, cazadores de tortuga y, además, pertenecer a familias que en algunas coyunturas han tenido un territorios 42-Especial

“EL MEDIO AMBIENTE: LA EMPRESA MÁS GRANDE DEL MUNDO" 
${ }^{18}$ La cacería de tortugas se practica muy esporádicamente pero no como una expedición organizada, sino como parte del hallazgo ocasional de algún pescador.

${ }^{19}$ Según Marcos Watts, un babitante de una zona costera cercana a Cartagena que conoció Islote en la época, quienes aparecen en la foto coincidian por ser quienes ostentaban el monopolio del comercio en el islote: "En ese tiempo los mayordomos de ahi del islote, eran Trinidad de Hoyos, habia Pepe (Tío Pepe) y Leoncio Barrios, eran los mandamases ahi en el Islote. / A.L.: ¿Por qué? (...) ellos eran los que acaparaban los grandes negocios" (Entrevista personal, Barú, 2011).

\section{territorias 42-Especial}

nivel de estatus social mayor al de otras por razones de prosperidad económica.

La caza de tortugas y la comercialización del extracto de su caparazón son uno de los ciclos económicos reiterados en las narraciones sobre la historia de la isla. Este duró treinta años, entre finales del siglo XIX y principios del XX. El material que se extraía era la concha de carey. Esta se comercializaba en Cartagena donde los comerciantes europeos la compraban para fabricar utensilios y artesanías (Heckadon, 1970, p. 24). Por su parte, la carne de otras especies como la tortuga verde (Chelonya mydas) se intercambiaba por otros productos agrícolas en las ciudades costeras.

En los relatos de los isleños mayores, el mar que rodea el islote era el albergue de peces, crustáceos, moluscos y tortugas. Las generaciones que crecieron en la isla durante la primera mitad del siglo $\mathrm{xx}$ cuentan que sus padres y abuelos pescaban desde la orilla. En los días de verano, cuando el agua estaba transparente, era posible ver alrededor de Islote una cantidad considerable de especies marinas. La cacería de tortugas se rememora como una expedición que implicaba una profunda especialización y saberes. Era posible pescar tortugas con dos técnicas: el clavo o el arpón y el trasmallo o red, que los mismos pescadores tejían. Además, era necesario tener capacidades cognitivas y una percepción aguda, pues la mayoría de expediciones de caza se hacían durante la noche, debido a la débil visión nocturna de estos animales. Algunos de los isleños más osados pescaban con arpón durante los días de verano. Así, el reconocimiento del color de la tortuga bajo el agua, el sonido o resuello del animal y la rapidez en la captura son algunas de las habilidades que debían tener estos hombres para tener una pesca exitosa. La población de cazadores fue disminuyendo con la demanda de carey, por un lado, y por el esfuerzo que requería tanto la fabricación de las redes, como la expedición de caza. Lo que continuó fue el buceo para la pesca de diferentes especies: crustáceos, peces y moluscos.

A pesar de la disminución de este tipo de pesca hasta su desaparición, ${ }^{18}$ los cazadores y buzos de la época fueron responsables de marcar un factor de prestigio relacionado no solo con el estatus económico, ${ }^{19}$ sino con lo que Boucek (1995) llamó dimensiones orgánicas del prestigio, que podríamos traducir como competencias o habilidades cognitivas y físicas para la pesca que adquirieron un valor social. En la actualidad, la cacería de tortugas es una práctica rara; no obstante, la construcción histórica del estatus basada en esta práctica configuró uno de los factores de prestigio masculino en la isla. Hoy en día, las prohibiciones recaen sobre otras especies, cuya pesca entra en conflicto con las políticas ambientales. 


\section{Reputación y habilidad vs. conservación}

Según el plan de manejo del PNNCRSB, la extracción de langosta y caracol es permitida cuando "se utilizan para la subsistencia teniendo en cuenta las tallas mínimas de captura" (UASPNN, 2006b, p. 131). El documento no define a qué se refiere con "subsistencia" ni la cantidad de pesca que esta implica; lo que sí establece son unas medidas o "tallas mínimas de captura"20 que deben tener los crustáceos y moluscos para ser pescados. De no respetar la pesca de las tallas mínimas estos no podrían reproducirse. Para el PNNCRSB, los isleños solo cumplen estos requisitos bajo medidas punitivas, es decir, "ejerciendo un control sobre los pescadores" (UASPNN, 2006b, p. 131). Pero la escasez progresiva de especies para la pesca hace que algunas especies que antes no se pescaban, ahora hagan parte del consumo y la venta locales.

La política de conservación de la institución es contradictoria pues combina la ya citada participación social de las poblaciones con el control punitivo. El análisis del plan deja entrever la carencia de medidas claras frente a los habitantes locales. En la realidad de Islote, la susodicha participación se traduce en viajes esporádicos de los funcionarios desde Cartagena para hacer talleres donde les enseñan a los pescadores qué es un plan de manejo, cuáles son las tallas mínimas a respetar y las artes de pesca prohibidas. ${ }^{21}$ En otras ocasiones, el control se ejerce mediante el decomiso de arpones y trasmallos. Es por eso que la relación de los isleños con los funcionarios oscila entre el rechazo por el carácter prohibitivo de la mayor parte de sus acciones y la aceptación tácita de su ingreso a la isla.

Tanto en el plan de manejo, como en conversaciones informales con algunos funcionarios de la institución, se pone en evidencia la dificultad de control de esta zona del parque. Por ejemplo, la sede operativa está ubicada en la isla vecina del islote llamada Múcura. Allí hay una casa donde vive temporalmente un guardaparques $^{22}$ y se alojan esporádicamente algunos funcionarios. También viven algunos infantes de marina, pues la Armada Nacional es la encargada de vigilar la zona marítima debido a que es un corredor de narcotráfico. Los isleños tienen poco contacto con los funcionarios del PNNCRSB y los infantes de marina. El guardaparques es amigo de una gran parte de los pescadores. Se supone que su función es la de controlar que no se pesque por encima de las tallas mínimas ni que se usen artes de pesca prohibidos. No obstante, él prefiere mantener buenas relaciones con los pescadores del archipiélago y evita entrar en conflicto siendo indiferente a estas prácticas.

La relación con el PNNCRSB es ambivalente: hay una dimensión individual de la presencia institucional que se caracteriza por la indiferencia o la aceptación mediante el humor y la camaradería. Las personas de Islote se han acostumbrado a la presencia
20 La talla mínima comercial de captura de un caracol pala (Strombus gigas) por ejemplo, es de 22 centímetros. Esto depende de la edad del animal, en este caso, los caracoles que se pescan en Islote tienen entre 2.7-4.5 años. Según el PNNCRSB, esta edad sobrepasa la talla minima requerida para la reproducción.

${ }^{21}$ Entre las artes de pesca probibidas están el uso de la dinamita, que tiene como fin adquirir carnada para la pesca. Así mismo, se probibe el "boliche de arrastre", una técnica mediante la cual se ata un boya pesada al trasmallo para arrastrar más fácilmente desde las embarcaciones todas las especies que surjan del fondo marino. Esta última técnica no es usada por los isleños, los habitantes de una población vecina llamada Berrugas son reconocidos por su uso.

22 Figura creada por la institución para incentivar el cuidado voluntario $y$ ciudadano. Existen diferentes categorias de guardaparques, en este caso, nos referimos a la institucional que apoya labores administrativas. Elguardaparques no era voluntario sino funcionario asalariado.

\section{territorias 42-Especial}


${ }^{23}$ El trasmallo es un arte de pesca formado por diferentes paños de red superpuestos, que sirve para la pesca desde la superficie. La dinamita era usada anteriormente, se generaba una explosion en el mar para aturdir los cardúmenes de peces.

${ }^{24}$ http://www.parquesnacionales.gov.co/portal/ es/parques-nacionalesrechaza-nueva-agresioncontra-funcionarios-de-laentidad-y-la-destruccionde-la-sede-en-isla-mucura/

\section{territarias 42-Especial}

permanente del guardaparques y a la presencia esporádica de los funcionarios. $\mathrm{Al}$ primero, lo han convertido en un habitante más al no interesarse por su identidad institucional a pesar de que siempre tiene un uniforme. Los segundos funcionarios son conocidos por todos. Algunos son víctimas de rechazo porque han decomisado material de pesca y han tenido encontrones con los pescadores. El funcionario es alto $\mathrm{y}$ de rasgos fuertes, algunos habitantes lo llaman "cabeza de marrano" para burlarse de él y lo ignoran cuando llega a la isla para acompañar algún taller con algún grupo de empleados de la institución. Entre ellos, siempre hay mujeres que al llegar despiertan los ánimos de coquetería de los hombres. Entre las funcionarias hay quienes conocen a algunas personas de Islote y pasan por las casas saludando tranquilamente. Otras, menos conocidas, se intimidan y se refugian en lugares como la escuela de la isla, que es el lugar donde se realizan reuniones y talleres.

La actitud general de los funcionarios del PNNCRSB cuando llegan a Islote es de prevención y expectativa. En la mayoría de los casos, llegan para realizar talleres con niños sobre temas relacionados con la conservación y otros con algunos pocos hombres que pescan y acceden a regañadientes a las peticiones de los funcionarios para hablar de temas comunes como la pesca de tallas mínimas, el uso controlado de artes de pesca como el trasmallo y la dinamita. ${ }^{23}$ Desde la perspectiva de una de las trabajadoras de la institución:
La población nos ve mal porque creen que nosotros llegamos a prohibir porque les decimos que no pesquen por debajo de las tallas mínimas. Las artes de pesca deben ser controladas y permitidas por las autoridades ambientales. Es una situación compleja porque estamos hablando de una comunidad de pescadores que siempre ha utilizado las mismas artes de pesca y que necesita subsistir $\mathrm{y}$ tratamos de que las acciones no solo se encaminen a la prohibición (funcionaria del PNNCRSB, junio de 2011).

Pero la pesca no es el único motivo de conflicto. Otras acciones como la tala del manglar que se encuentra en islas aledañas con el fin de extraer madera para construcción de ranchos y botes o para preparar terrenos para el turismo son otras de las causas de la disputa entre los habitantes y la institución. Una situación reciente refleja esta problemática. En el año 2018, los guardaparques que habitaban en la sede de la institución, ubicada en la isla de Múcura, denunciaron que un grupo de personas talaba árboles, rellenaba un terreno y construía una estructura ilegalmente en la vecina isla de Tintipán,

lo que motivó el control por parte del personal del PNNCRSB y la Fiscalía. Tras el operativo algunas personas presuntamente de las comunidades de esa zona, se trasladaron a Isla Múcura, donde agredieron a los funcionarios y causaron destrozos a la sede de la entidad. ${ }^{24}$ 
Nunca se reveló el nombre de los agresores y tampoco se confirmó si pertenecían a Islote o eran forasteros que pensaban invadir terrenos ajenos. No obstante, la entidad acusó a personas isleñas de ser los actores del hecho, lo cual ocasionó una serie de críticas, disgustos y rumores entre la gente de la isla. Muchos rechazaron la acusación, diciendo que "si las personas del medio ambiente regresaban, no los dejarían entrar al islote".

En los últimos años, el turismo ha reemplazado la pesca como forma de subsistencia principal, debido a la escasez de pescado a causa de la sobreexplotación por la necesidad de subsistencia de la población, pero en mayor medida por la pesca a gran escala que concentran empresas multinacionales. ${ }^{25}$ Otras causas son la presión sobre las playas y los bosques de manglar que incrementa el riesgo de erosión y el deterioro del fondo coralino, que afecta el ecosistema que sustenta a los peces y crustáceos de los que solían vivir los isleños en tiempos mejores. El turismo en el archipiélago es también un bien limitado, pues son pocas las playas de las que se puede sacar provecho para recibir turistas, pero son muchas las familias isleñas que requieren de este ingreso para su supervivencia.

\section{El turismo y la supervivencia vs. la conservación}

Desde los años setenta un grupo pequeño de familias isleñas comenzó a vender, esporádicamente, gaseosas a turistas que, de vez en cuando, llegaban en lanchas desde las costas del Golfo de Morrosquillo. La primera playa turística se llama La Punta y queda en la isla vecina de Múcura (figura 4). Como lo relata el señor Vitola, uno de sus habitantes:

los primeros que vendían ahí en la playa era mi persona, junto con "el Guacho", "Gregorio" y "Justico", yo vendía gaseosa y cerveza... yo en el agua salada enfriaba... venían varios [turistas], pero no muchos... Yo tenía como 22 o 25 años y cuando me retiré ahí fue cuando me fui pa' los cayos, más o menos de los años 80 (Comunicación personal, junio 2011).

El turismo no es una economía nueva en este archipiélago, pero se intensificó desde los años 80 y con el auge del narcotráfico. Varios fueron los narcotraficantes que construyeron casas de recreo y abrieron las islas al comercio turístico. Otros actores que no eran narcotraficantes, como académicos y biólogos, también construyeron casas de recreo. En el municipio de Tolú (Sucre) se gestó el comercio turístico hacia las islas de San Bernardo con la figura de las llamas marinas o asociaciones de comerciantes que compraron lanchas para el transporte diario de turistas provenientes de ciudades como Bogotá, Medellín, Cali, Cartagena y Montería. Esto ocurrió al mismo tiempo de la construcción, hacia finales de los años 90, de hoteles de lujo
${ }^{25}$ Según la conversación personal con el antropólogo y geógrafo Alejandro Camargo, la crisis de la pesca recae en el pequeño pescador artesanal ya que el monopolio del mar se concentra en grandes empresas que cultivan peces y mariscos. Estas tienen la mayor parte del comercio mundial y son las causantes de la escasez con consecuencias dramáticas en la economía del pescador artesanal.

territarias 42-Especial

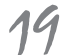

“EL MEDIO AMBIENTE: LA EMPRESA MÁS GRANDE DEL MUNDO" 
Figura 4. Playa La Punta en la isla de Múcura

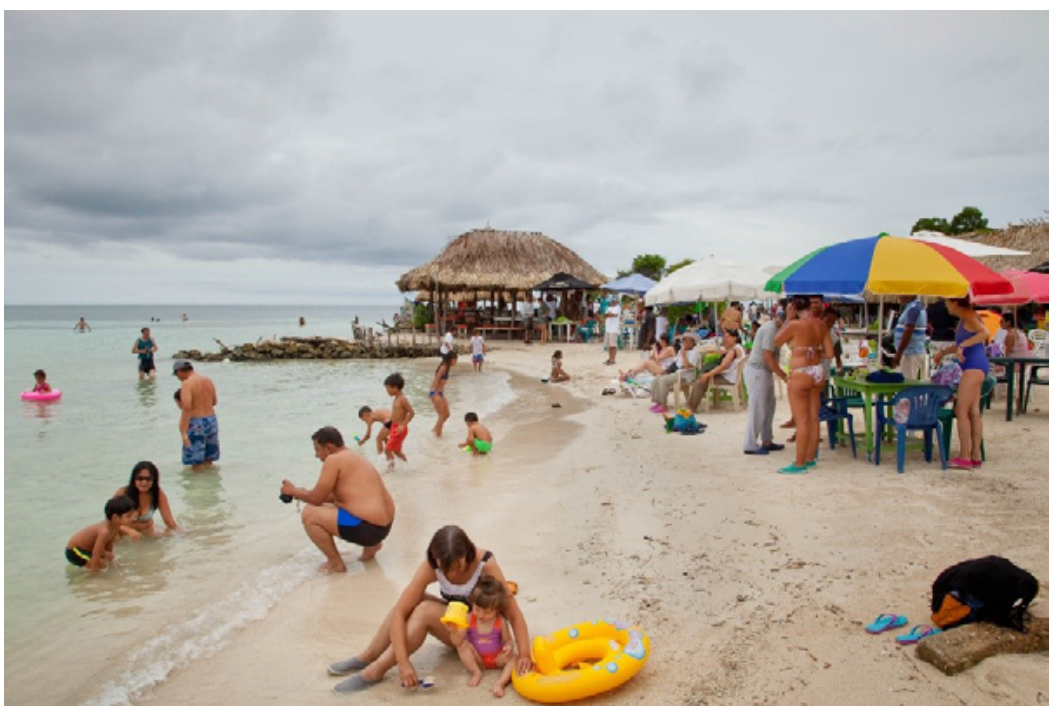

Fuente: archivo de Jonathan Adams.

${ }^{26}$ Cálculo becho en Google Earth.

\section{tersitorios}

42-Especial por parte de empresarios provenientes de las mismas ciudades.

El fragmento citado un párrafo atrás es parte de la entrevista que le hice al señor José Vitola, habitante del caserío de Chupundún, quien da cuenta de la transformación de Múcura de una isla de cultivo a una zona turística. Relata la llegada de los primeros isleños que comenzaron a usar este terreno como un lugar turístico. Los tres sobrenombres que menciona: "El Guacho", "Gregorio" y "Justico", como los primeros que vendieron productos allí, son hijos de José Felipe Morelos o "Tío Pepe" y hoy en día tienen el monopolio del comercio de víveres en la playa.

En los relatos sobre las condiciones pasadas de la playa La Punta, salen a relucir los recuerdos de las tortugas marinas que llegaban a anidar en sus orillas: "cuando yo conocía La Punta, esa punta estaba sucia y ahí bajaban hasta el carey a anidar [...] más de 40 años hace eso [...]”, decía Josefina Zúñiga, otra de las mujeres del poblado. La extensión de la playa también parece haber cambiado. Cuenta José Vitola: "La Punta llegaba hondo [era más extensa], sí, porque veníamos a jugar bate [béisbol], cuando bateábamos esa bola salía lejos". Actualmente, tiene $120 \mathrm{~m}$ de longitud ${ }^{26} \mathrm{y}$ una profundidad de $30 \mathrm{~m}$, donde apenas caben los visitantes.

Durante temporada alta: diciembreenero, semana santa y junio-agosto llegan a La Punta hasta treinta lanchas turísticas en un día, lo cual corresponde a 200 viajeros diarios. En temporada baja: febreromayo y septiembre-noviembre, este número desciende a cincuenta personas por día (UAESPNN, 2006b, p. 15l). Existen varios kioscos administrados por los isleños: restaurantes, puestos de bebidas alcohólicas y de cocteles de mariscos y dos sitios de venta de artesanías. Grupos de tres a cinco mujeres isleñas, todas madres, se pasean durante el día ofreciendo a los turistas dulces típicos. Dentro de estas familias hay dos que tienen el monopolio de los servicios turísticos en la isla: los Berrick y los Morelos. Las cabezas principales de cada familia gestionan los restaurantes y trabajan en grupos de cooperación con sus allegados.

En otras islas, como Tintipán, se combina el turismo privado de familias que 
compraron terrenos a isleños que antes eran poseedores de lotes sobre la playa, con el reciente turismo playero, cuyas dinámicas imitan las dinámicas de la playa La Punta de Múcura. Estos son atendidos por otras familias isleñas que venden almuerzos, cuyo costo está incluido en el pago de un "pasadía”, es decir, un paquete que se vende desde las costas del Golfo de Morrosquillo e incluye el transporte y el consumo.

En el año 2014, se creó un nuevo centro turístico dirigido a extranjeros que se alojan en un hotel llamado La Casa en el Agua (figura 5), a pocos metros de Islote. Este se asienta sobre un antiguo cayo. Como en Islote, este hotel no tiene playas, pero tiene una capacidad de alojamiento de unas veinte personas que se acomodan entre habitaciones y hamacas.

La creación de dicho hotel fue una oportunidad laboral para hombres y mujeres jóvenes, cocineros y mucamas isleños. Además, se forjaron lazos de amistad y alianza con algunos de sus administradores y propietarios, e incluso el propietario, que es extranjero, tiene hijos con una isleña. Las dinámicas del turismo activaron nuevos vínculos y generaron una relación de codependencia y relaciones de poder entre los empresarios y algunos hombres y mujeres isleños: estos últimos son empleados necesarios para los empresarios, pero al mismo tiempo, los isleños necesitan de estas empresas, pues son su única fuente de ingresos por el turismo en el archipiélago.
Figura 5. Hotel La Casa en el Agua

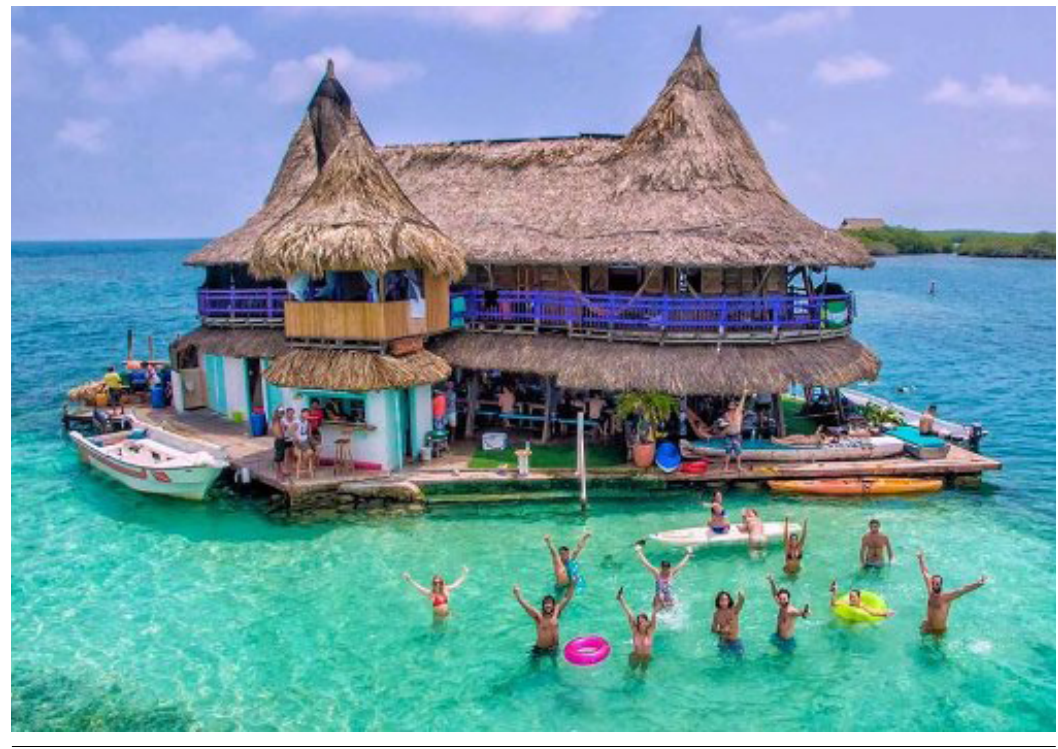

Fuente: https://casaenelagua.com/

Además, los empresarios se convierten en sus amigos y padrinos.

El discurso de los isleños frente al turismo consiste en persuadir al visitante para que utilice el máximo de los servicios ofertados: careteo o buceo superficial con máscara, consumo de bebidas y cocteles de mariscos y paseos en lancha o en motos acuáticas. Para lograrlo, la herramienta principal es el discurso sobre las "bellezas del mar": "con el careteo podrán ver estrellas de mar, ver distintas clases de peces y conocer el coral" y añaden un consejo para proteger el ecosistema: "pero les vamos a pedir que no se lleven las estrellas de mar ni pisen el coral, pues tenemos que proteger el medio ambiente". territarias 42-Especial

"El MEDIO AMBIENTE: LA EMPRESA MÁS GRANDE DEL MUNDO" 
Figura 6. Juvenal Julio, trabajador de la playa hablando a los turistas sobre los cangrejos

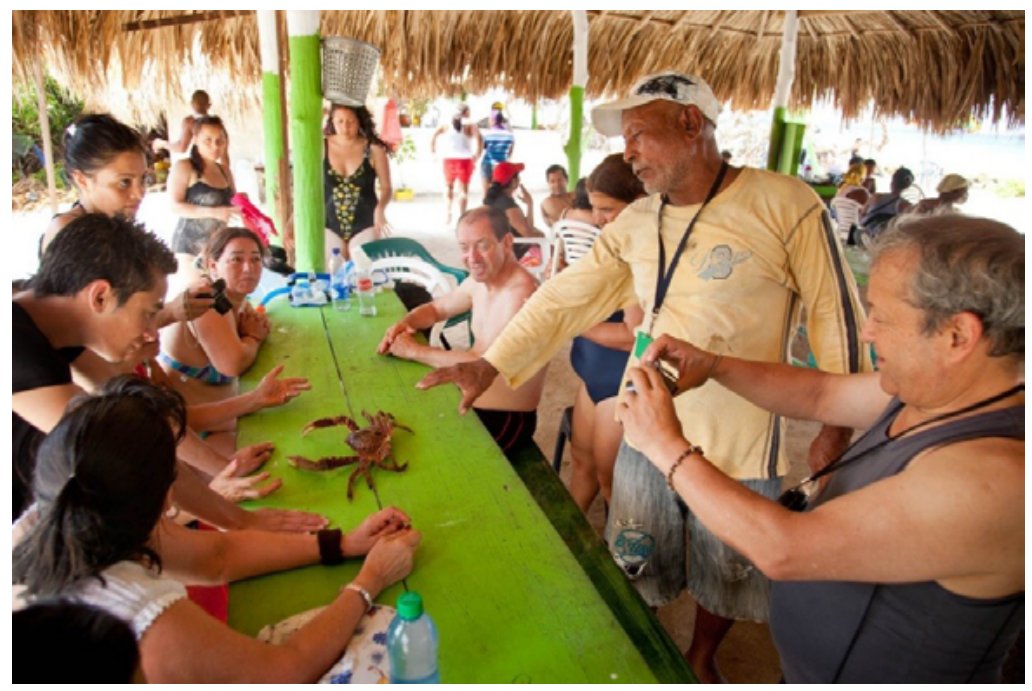

Fuente: Jonathan Adams. Múcura, abril de 2010.

\section{tersitarios 42-Especial}

Este discurso deja entrever la incorporación de las ideas atribuidas tanto por las entidades ambientales, como por los viajeros a los isleños como nativos capaces de resguardar la naturaleza, que surge de la confrontación de los lugareños con la presencia de los funcionarios y los visitantes. La valorización del nativopescador como garante de la naturaleza es característica de sociedades sometidas a transformaciones socioeconómicas y a marcos estatales de protección ambiental (Clerc-Renaud, 2005). En el Islote, el uso de estos discursos en el encuentro con los turistas (figura 6), es un recurso $\mathrm{y}$ una forma de construirse y asumirse como nativos conscientes del cuidado de las especies.
El turismo combina iniciativas privadas hoteleras con algunos negocios de isleños y particulares. Los dos tipos de ofertas tienen, sin embargo, escalas distintas en las relaciones de poder. Las primeras, acaparan la mayor parte de los terrenos en las islas de Múcura y Tintipán (figuras 7 y 8). Los segundos, son kioscos hacinados en las pocas playas que existen en las dos islas.

En Tintipán, la mayor parte de propiedades son casas de recreo y pequeños hostales. En las lagunas interiores, anclan lujosos yates privados de turistas extranjeros: canadienses, franceses, alemanes; esta es una presencia poco notoria para los isleños, pues, generalmente no salen de sus embarcaciones y prefieren la tranquilidad de las aguas de Tintipán. Permanecen pocos días en el archipiélago y luego siguen su camino hacia Panamá.

En Múcura existen cuatro sitios turísticos: un hotel llamado Club Cien, una cabaña construida hace más de cuarenta años por un biólogo bogotano llamada Dahalandia, que es aledaña al caserío de Chupundún, la playa turística que usufructúan los isleños y se conoce como La Punta. Por último, el hotel Punta Faro que cubre la tercera parte de la superficie total de la isla y se concibe en la industria turística local como resort o complejo vacacional.

El predominio de hoteles y casas de recreo privadas que pertenecen a propietarios externos a la isla hace que los isleños estén subyugados a la autoridad 
Figura 7. Isla de Tintipán

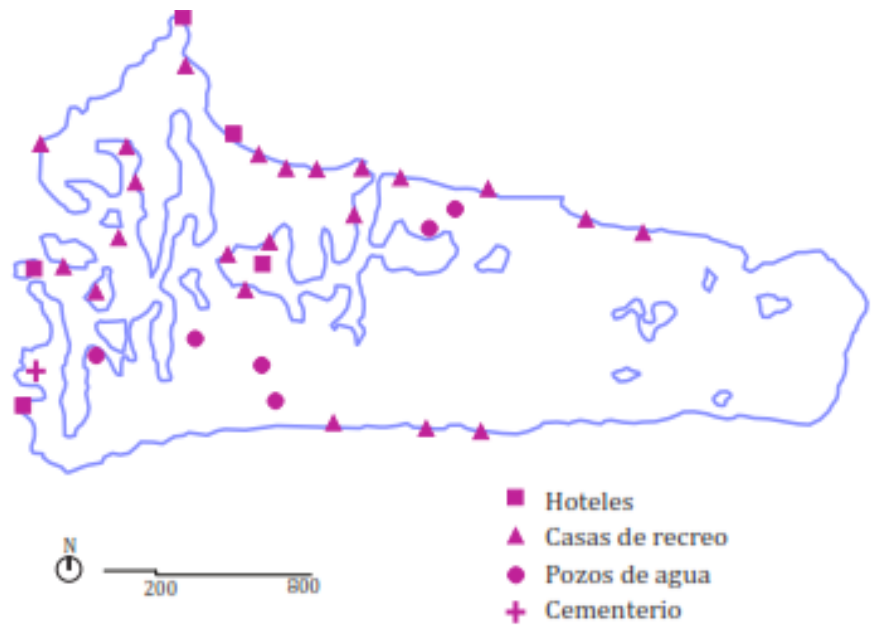

Fuente: Adaptado de Arango (2013, p. 270).

Figura 8. Isla Múcura

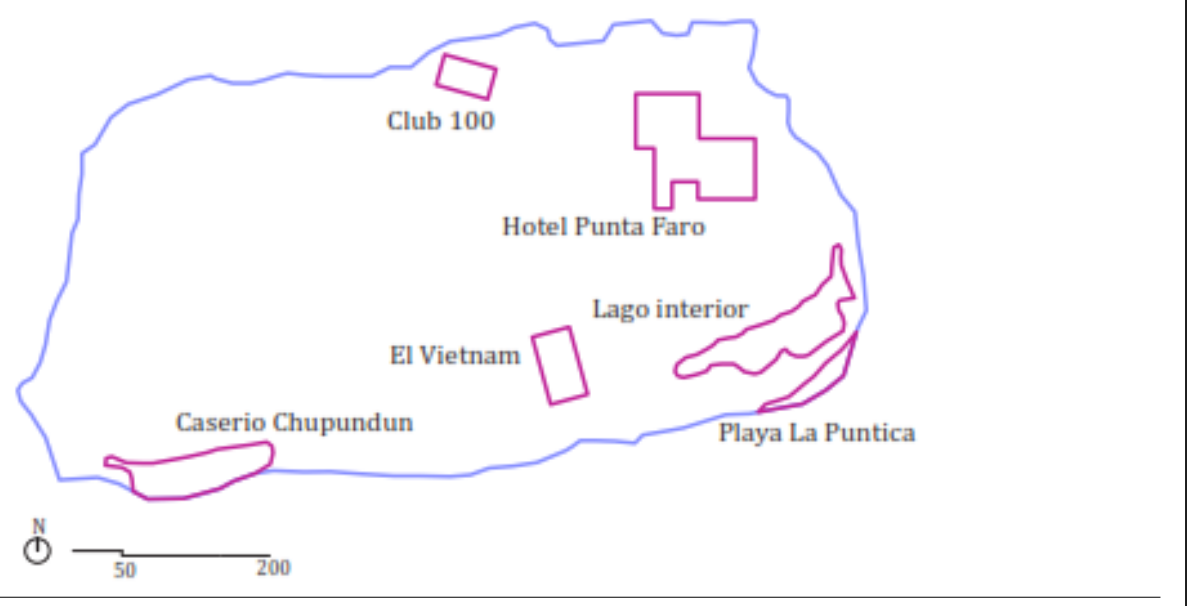

Fuente: Google Maps, Diseño: Diego Pérez.

y el poder económico de empresarios Aunque los negocios o kioscos que se turísticos. Un ejemplo es el poder que el ubican allí son de familias isleñas, es el gerente del hotel Punta Faro en Múcura tiene sobre el uso de las playas de la isla. gerente de este resort quien ejerce un control sobre las personas que tienen el

“El MEDIO AMBIENTE: LA EMPRESA MÁS GRANDE DEL MUNDO”

tersitorios 42-Especial

23 
27 Según el artículo 2 de la Ley 472 de 1998 las Acciones Populares son los medios procesales para la protección de los derechos $e$ intereses colectivos. Las acciones populares se ejercen para evitar el daño contingente, hacer cesar el peligro, la amenaza, la vulneración o agravio sobre los derechos e intereses colectivos o restituir las cosas a su estado anterior cuando fuere posible.

28 Antiguo Instituto Colombiano de Desarrollo Rural.

\section{territarias 42-Especial}

derecho a usufructuarlas. Él decide, en palabras de los isleños, quién trabaja o no en la playa.

La desigualdad en esta relación hace que el ejercicio de las instituciones ambientales sobre el turismo reafirme el descontento de la población frente a las medidas que esta impone. Existe una asimetría en el nivel de las sanciones ambientales. Estas recaen en todos los actores, por ejemplo, se han llevado a cabo sanciones ambientales a varios propietarios de hoteles y casas de recreo, en islas como Múcura en Tintipán, especialmente por la construcción de espolones y muros de contención a miembros de familias pudientes de la ciudad. Se llevan a cabo investigaciones judiciales $\mathrm{y}$, en algunos casos, se imponen sanciones económicas. Lo mismo les ocurre a familias isleñas que hacen muros de contención en concreto para proteger sus propiedades de la erosión y las inundaciones causadas por el oleaje. Sin embargo, los dos actores tienen capitales económicos y jurídicos distintos: mientras que los primeros tienen las posibilidades de pagar sanciones costosas y abogados, los segundos carecen de estas.

A pesar de lo anterior, en el año 2014 algunos abogados, que trabajaron como voluntarios junto con representantes de la Junta de Acción Comunal del archipiélago, emprendieron una acción popular $^{27}$ contra el Ministerio de Ambiente y Desarrollo Sostenible, Incoder, ${ }^{28}$ Cardique (Coorporación Autónoma del Canal del Dique), Dimar (Dirección
Gerenal Marítima) y la Alcaldía Distrital de Cartagena por "no cumplir con el deber de conservar y preservar los recursos naturales de los archipiélagos de Nuestra Señora del Rosario y de San Bernardo". En noviembre de 2011 el Consejo de Estado desató recurso de apelación ordenando "frenar el deterioro de los recursos naturales de estos archipiélagos, la tala de manglares y bosques secos, la descarga de sedimentos al agua, el turismo masivo y la pesca indiscriminada", entre otros factores (Niño \& Posada, 2014, p. 15). Para responder a este requerimiento, el Incoder y una universidad privada se fusionaron con el fin de hacer la consulta previa con la población, para establecer las pautas de lo que luego sería el Plan de Acción Integral como Estrategia de Administración de los Baldíos de los Archipiélagos de Nuestra Señora del Rosario y San Bernardo, teniendo como entidad garante al Ministerio del Interior. No obstante, este proceso no tuvo éxito, ya que "las comunidades consultadas no aceptaron las condiciones del proyecto y por ende no permitieron el ingreso de los investigadores a campo para la toma de datos y la realización e implementación de diversas actividades contempladas" (Niño \& Posada, 2014, p. 15).

Aunque los autores del documento citado no mencionan ni las condiciones del proyecto ni las razones del rechazo por parte de los pobladores, estas situaciones se repiten constantemente en Islote y dan cuenta de la desconexión entre las 
iniciativas ambientales de las instituciones y las expectativas de los pobladores.

Por otro lado, aunque las instituciones involucradas en este proceso afirman que la acción popular fue emprendida por los habitantes de las islas para la protección del medio ambiente, la situación da cuenta de que la defensa ambiental es emprendida por actores externos, en este caso abogados provenientes de otras ciudades $\mathrm{y}$ algunos aliados internos, quienes no representan necesariamente a toda la población y desafían las prácticas locales que contradicen las demandas contenidas en la acción popular. Por ejemplo, la tala de manglar es ejercida por personas externas o habitantes locales en busca de lotes para vender o explotar turísticamente, debido a las necesidades de supervivencia. Al imponer una acción en contra del Estado por el deterioro ambiental, los abogados y líderes locales incluyen esta práctica de tala dentro de las razones de la demanda, sin tener en cuenta que muchas de estas actividades son realizadas por habitantes locales. Así, la acción popular termina por afectar y criminalizar a los mismos isleños. Lo anterior tiene tres efectos. El primero, un efecto boomerang en el que las acciones populares para pedir atención del Estado frente a la conservación resultan por afectar las prácticas de supervivencia de los habitantes de la misma población que demanda. El segundo, se acentúa la visión negativa de los habitantes frente a las instituciones ambientales. El tercero, se reconfigura la imagen de las instituciones que son percibidas ahora como entes burocráticos y externos: un otro que en muchos casos no es visto como representación del Estado, sino como una empresa.

\section{“La empresa más grande del mundo": reconfiguraciones locales de la institucionalidad ambiental}

La inestabilidad en la organización política del Islote cambia la estructura de las organizaciones del PNNCRSB en la isla. Una de estas es la cooperativa Marclaro, una instancia creada, entre otras cosas, con el fin de incentivar prácticas de pesca acordes con los principios de conservación de la institución, ${ }^{29}$ ejercer control y promover el uso equitativo de los bajos ${ }^{30}$ de pesca. El presidente de la cooperativa es un pescador que recibía un salario mensual de la unidad administrativa del PNNCRSB como retribución a su servicio y es considerado uno de los mejores pescadores de la isla. No obstante, él no tiene un papel activo en la vida política de la isla, es respetado por sus competencias y saberes de pesca, pero su autoridad en la cooperativa es nula. Su actuar frente a las expectativas del PNNCRSB es ambivalente: es un pescador que lucha diariamente por llevar un sustento a su familia y en su discurso no tiene ambiciones de conservar las especies ya que, debido a la necesidad, pesca especies que alcanzan las "tallas mínimas" establecidas. Sin embargo, él es un aliado de los funcionarios cuando van a la isla y esto lo hace afirmar que la institución, conocida
${ }^{29}$ Según el plan de manejo vigente, la utilización de métodos inapropiados y la pesca intensiva han ocasionado grandes perjuicios al medio natural. "A pesar que el método de pesca con dinamita no es nombrado por los pescadores aún es ampliamente usado en el parque, causando la destrucción de importantes áreas de arrecifes coralinos, causando un perjuicio para los mismos pescadores, los que con el tiempo ven reducido el recurso pesquero local” (UAESPNN, 2006b, p. 147). Además de la dinamita, el deterioro de los arrecifes de coral también se debe a la pesca con trasmallo. La extracción de la langosta y el caracol es permitida cuando se utilizan para la subsistencia teniendo en cuenta las tallas minimas de captura (UAESPNN 2006, p. 131).

${ }^{30}$ Sitio profundo en el que se echan las redes para pescar o se pesca por inmersión del pescador.

\section{tersitarios 42-Especial}

“EL MEDIO AMBIENTE: LA EMPRESA MÁS GRANDE DEL MUNDO"

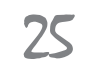




\section{territorias} 42-Especial en la isla como "El Medio Ambiente" es, de acuerdo con sus palabras "la empresa más grande del mundo".

La etiqueta de "Medio Ambiente" es la que se usa regularmente entre los isleños para designar a todas las entidades del Sistema Nacional de Áreas Protegidas, especialmente al PNNCRSB. Con esto, la población pone en evidencia que no están asumiendo el concepto de ambiente como una categoría equivalente al entorno marítimo y costero del que hacen parte, sino a la presencia colectiva de un ente estatal. Los funcionarios son los mediadores entre esta figura y los isleños.

Siguiendo el argumento de este artículo, la etiqueta de medio ambiente se entiende como una muestra de las reconfiguraciones locales de la institucionalidad, pues moviliza una serie de significados disímiles a los que los funcionarios tienen sobre sí mismos y su trabajo en la isla. Al evocar al "medio ambiente", los habitantes simplifican y hacen legible su representación, que, parafraseando a Hall (1997) se entiende como el proceso mediante el cual el significado es producido e intercambiado entre los miembros de una cultura. Incluye el uso del lenguaje, los signos y las imágenes que representan cosas. Al evocar al medio ambiente como una empresa, el pescador lo separa de su sentido estatal y lo convierte en un actor externo, que le provee durante temporadas de un salario por ser un aliado como presidente de Marclaro. Al decir que es la empresa "más grande del mundo", el isleño amplía la escala geográfica y el alcance de la institución: ya no se trata solo de una institución, sino de un conjunto de actores que confluyen en uno solo.

Por lo menos hasta hace algunos años, la mayor parte de isleños no percibían al PNNCRSB como una unidad, sino como parte de un colectivo conformado por las $O N G$, fundaciones e instituciones que mediante los funcionarios llevaban a la isla folletos, conocimiento técnico y experto, videos, presentaciones, talleres de cartografía social, entre otras metodologías, que en el lenguaje institucional se llamarían participativas. El título de medio ambiente, que sirvió para designar este colectivo, pone en evidencia que hay lecturas disímiles de lo que esta categoría representa para quienes habitan la isla y las instituciones de conservación. En un sentido general, los adultos, tanto mujeres como hombres del Islote - a excepción de algunos interlocutores entre la población y la entidad que manejan un discurso público en el diálogo con los funcionarios- no conciben el ambiente como el entorno natural, tal y como lo entiende la institución, sino como un nombre propio institucional.

Los habitantes del Islote no parecen observar el "ambiente" como un sinónimo de entorno natural, estas categorías no figuran tampoco en el lenguaje cotidiano. Lo que para la institución significa el medio ambiente, parece ser para los isleños una serie fragmentada de especies, lugares y paisajes. Los peces no se clasifican por 
especie sino por cualidad: por ejemplo, la clasificación de peces define los distintos tipos por las cualidades de su carne, por el precio y por el sabor entre pescado fino y pescado basto. El primero se atribuye a peces que se consideran de buena calidad y que se destinan especialmente a la venta como el pargo (Lutianus aynagria) o la sierra (Scombenus morio). El segundo está formado por especies que se consumen localmente y su carne se considera de menor calidad como el mero (Serranus morio) o la cherna (Serranus striatus). La carnada es el nombre destinado a las sardinas y los calamares que sirven para la pesca en superficie o pelágica; los habitantes de la isla los reconocen por su movimiento en cardúmenes.

El mar, por su parte, se concibe como un espacio con geografías disímiles que juegan un papel fundamental en la configuración socioespacial de la isla. La gente suele distinguir entre el agua salá que es la porción de mar que rodea la isla, a la cual se accede fácilmente y es de uso doméstico, y el mar abierto. El baño, el lavado de ropa y enseres y la defecación son algunas de las acciones que se llevan a cabo en el agua salá. El mar abierto es un territorio que los hombres ${ }^{31}$ conocen bien debido a los recorridos y jornadas de pesca que los hacen expertos en identificar los bajos de pesca, la dirección de las corrientes y los caminos submarinos que permiten o no anclar o pasar en lanchas (Leiva Espitia, 2016). El entorno para los isleños no es definido como un conjunto de elementos naturales. Es un conjunto diferenciado de seres, especies, formas de vegetación y tipos de aguas, que sería imposible enmarcar en una categoría genérica como medio ambiente.

\section{Conclusión}

En su estudio sobre los Gimi de las tierras altas de Papúa-Nueva Guinea, West (2006) cuenta que varios agentes coloniales llegaron a los poblados que están rodeados por las montañas llamadas Crater Mountain. Años más tarde, un oficial de policía que, junto con un grupo de funcionarios nativos que patrullaban entre los montes de Goroka y Mount Karimui, llegó a una aldea y la bautizó con el nombre de uno de los clanes existentes en la zona Maimafu. Parafraseando a West (2006), este nombre fue parte de un largo proceso de simplificación colonial para hacer legibles estas tierras altas al gobierno colonial (p. 12). Con el tiempo, la etiqueta se comenzó a utilizar en otras aldeas. Con este ejemplo, West (2006) muestra la capacidad que tienen actores externos, estatales y no estatales, de producir representaciones y prácticas sobre los espacios y hacerlas funcionales dentro de las mismas poblaciones locales.

La razón por la cual lo considero pertinente es porque ese proceso de simplificación social que describe el antropólogo, que ocurre desde afuera hacia adentro - es decir, desde los actores coloniales, gubernamentales, turísticos y académicos,
${ }^{31}$ Algunas mujeres dominan la navegación en botes $y$ lanchas de motor fuera de borda. Entre ellas, hay quienes se desplazan entre una isla y otra para trabajar en playas o casas turisticas o recoger agua que se extrae de pozos. No obstante, el mar abierto es el terreno masculino. Los hombres lo navegan, lo conocen, conocen sus bancos de pesca, son quienes lo dominan.

\section{territarios 42-Especial}

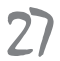

“EL MEDIO AMBIENTE: LA EMPRESA MÁS GRANDE DEL MUNDO" 


\section{tersitorias} 42-Especial hacia las poblaciones locales-, también ocurre de adentro hacia afuera: desde los habitantes se hacen legibles los grupos de funcionarios, instituciones, académicos, ONG y turistas. En el caso de Islote, el proceso de simplificación de la institucionalidad ambiental, representada principalmente por los funcionarios del PNNCRSB, se reúne en la etiqueta del medio ambiente y la concepción de este como una gran empresa.

Estas simplificaciones sociales tienen efectos en estos procesos y en su interacción. En el discurso del PNNCRSB las políticas de conservación ambiental incluyen a las comunidades locales como valores y agentes de la conservación (UAESPNN, 2006b). Como lo muestra Goldman (2003) para el caso de Tanzania, esta es una forma idealizada en la que las poblaciones son percibidas como unidades homogéneas a las que se les otorga la responsabilidad del manejo de su entorno. Pero en la práctica, la revisión de la organización política propia de Islote, la relación histórica entre la pesca y el prestigio y el turismo como una forma de supervivencia que toma cada vez más espacios deja entrever que esta "agencia", a la que apela en su discurso la institución ambiental para mostrar a los pobladores como posibles aliados en la conservación, no es interpretada de la misma manera en las prácticas locales. En muchos casos es instrumentalizada como lo muestra el ejemplo citado en este texto, que se refiere al uso del discurso de "cuidado de la naturaleza", que se activa en la interacción de los isleños, para atraer a los turistas de la playa La Punta.

Antes que ver en esta situación un conflicto bipolar entre instituciones y habitantes, podríamos entender estas reinterpretaciones, usos y relaciones entre las poblaciones y los funcionarios en el sentido de West (2006): como la convergencia de diferentes comunidades que tienen distintos marcos de representación y percepción de la naturaleza, la organización social y la conservación. La presencia de las instituciones ambientales se separa de su significado local y adquiere otra forma, se convierte en un espacio de representación externa que se materializa en la presencia esporádica de funcionarios, en cartas que contienen sanciones ambientales y, en pocos casos, en vínculos de camaradería entre isleños y funcionarios. Por su parte, la entidad ambiental tiene una visión estática de los locales: el plan de manejo del PNNCRSB no ha sido actualizado desde 2006 a pesar de que las condiciones ambientales han cambiado por el aumento del turismo. Este se convierte en un requisito burocrático $\mathrm{y}$, aunque pretende ser un insumo de política pública ambiental, es un texto que solo condensa información ilegible para muchas personas, habitantes o externas, que no están familiarizados con el lenguaje técnico.

Tal vez si las entidades ambientales exploraran y actualizaran sus formas de organización social, de la percepción del entorno y las formas locales de interpretar 
la presencia institucional, la llamada participación social sería más efectiva como parte de la política ambiental. Los habitantes locales parecen conjugar competencias para la adaptación, supervivencia y el arraigo. Estos no son novatos aprendiendo a cuidar la naturaleza, sino grupos sociales que, desde diferentes géneros y generaciones, participan en la construcción del otro institucional y en la producción social del entorno.

\section{Referencias}

Arango, L. (2013). Les réseaux d'approvisoinement en eau. El Islote (Colombie), un indicateur des dynamiques sociopolitiques locales. Journal des anthropologues, (132-133), 267-289.

Anderson, B. (1993). Comunidades imaginadas. Buenos Aires: Fondo de Cultura Económica.

Agrawal, A. (1995). Dismantling the divide between indigenous and scientific knowledge. Development and Change, 26(3), 1-43. https://www.doi. org/10.1111/j.1467-7660.1995. tb00560.x

Ariel de Vidas, A. (2007). The symbolic and ethnic aspects of envy among a Teenek community. Journal of Anthropological Research, 63(2), 215-237. https://www.doi.org/10.3998/ jar.0521004.0063.206

Boucek, J. (1995). La sociología del prestigio. Revista de Estudios Políticos, 94, 81-98.
Bougerol, C. (2008). Actualité de la sorcellerie aux Antilles. Cabiers d'Études Africaines, XLVIII(1-2), 267-281. https://www.doi.org/10.4000/ etudesafricaines.10612

Cano, M., \& Valderrama, J. (1996). Archipiélagos del Caribe colombiano. Bogotá: Banco de Occidente.

Clerc-Renaud, A. (2005). Le «natif», le touriste et la protection de l'environnement: la réthorique de la différence dans une localité du nord-Ceará. Lusotopie, XII(1-2), 3-19. https:// www.doi.org/10.1163/176830840120102002

DeLoughrey, E. (2018). The sea is rising: visualising climate change in Pacific Islands. Pacific Dyamics, Journal of Interdisciplinary Research, 3(2), 186-197.

Drouin, J.-M., \& Foucault, A. (1997). Rêve, expériences et réalité. En J. DenisVigne (Comp.), Iles, vivre entre ciel et mer (pp. 9-21). Paris: Museum National D'histoire Naturelle.

Durán, C. (2009). “Gobernanza en los Parques Nacionales Naturales colombianos: reflexiones a partir del caso de la comunidad orika y su participación en la conservación del Parque Nacional Natural Corales del Rosario y San Bernardo". Revista de Estudios Sociales, 32, 60-73.

Escobar, A. (1998). Whose knowledge, whose nature? Biodiversity, conservation and the political ecology of social movements. Journal of Political tersitarias 42-Especial 


\section{territarias 42-Especial}

Ecology, (5), 53-82. https://www.doi. org/10.2458/v5il.21397

Foster, G. M. (1965): El carácter del campesino. Revista de Psicoanálisis, Psiquiatría y Psicología, (1), 83-106.

Foster, G.M. (1972). Anatomy of envy: a study in symbolic behavior. Current Anthropology, 13(2), 163-202. https:// www.doi.org/10.1086/201267

Goldman, M.(2003). Partitioned nature, priviledge knowledge: community based conservation in Tanzania. Development and Change, 34(5), 833862. https://www.doi.org/10.1111/ j.1467-7660.2003.00331.x

Gregory, D., Johnston, R., Pratt, G., Watts, M. J., \& Whatmore, S. (2009). Dictionary of human geography. West Sussex: Wiley-Blackwell.

Hall, S. (Ed.). (1997). Representation: Cultural representations and signifying practices. London: Sage Publications.

Heckadon, S. (1970). "El Islote": estudio de una comunidad de pescadores, Islas de San Bernardo. Bogotá: Universidad de los Andes.

Hoffmann, O. (2007). Comunidades negras en el Pacífico colombiano, innovacionesy dinámicas étnicas. Quito: Abya-Ayala.

Holmes, G. (2007). Protection, politics and protest understanding resistance to conservation. Conservation and Society, 5(2), 184-201. Recuperado de www.jstor.org/stable/26392880

Kelman, I. (2006). Island security and disaster diplomacy in the context of climate change. Les Cabiers de la Sécurité, 63,
6-94. Recuperado de http://www. disasterdiplomacy.org/publications. html\#kelman2006

Kelman, I. (2010). Hearing local voices from small island developing states for climate change. Local Environment, 15(7), 605-619. https://www.doi.or g/10.1080/13549839.2010.498812

Leiva Espitia, A. (2016). Yo me la paso de isla en isla: formas de habitar e interacciones sociales en el Islote, Caribe colombiano. (Tesis de doctorado, École Pratique des Hautes Études, París, Francia).

Niño, L.M., \& Posada, C. (2014). Fundamentos de ordenación pesquera en áreas marinas. Guía del curso. Cartagena de indias DT: Incoder. Recuperado de http:/ /observatorioirsb.org/ web/wp-content/uploads/2015/11/ fundamentos-de-ordenacion-pesqueraen-areas-marinas.pdf

Royle, A., \& Brinklow, E. (2018). Definitions and typologies. En G. Baldacchino (Ed.), The Routledge international handbook of island studies, a world of islands (pp. 3-20). New York: Routledge.

Scott, J. (2003). Los dominados y el arte de la resistencia. Tafalla: Ediciones Era.

Thing, S. J., Jones, R., \& Birdsall Jones, C. (2017). The politics of conservation: Sonaha, Riverscape in the Bardia National Park and Buffer zone Nepa. Conservation and Society, 15(3), 292303. https://www.doi.org/10.4103/ cs.cs_15_2 
Tönnies, F. (1947). Comunidad y sociedad. Buenos Aires: Losada.

UAESPNN, NOAA, Invemar. (2006a). Establecimiento de un modelo de monitoreo socioeconómico para el Parque Nacional Natural Corales del Rosario y San Bernardo. Santa Marta: Instituto de Investigaciones Marinas y Costeras "José Benito Vives de Andreis" - Invemar.

uaespnn. (2006b) Plan de Manejo del Parque Nacional Natural Corales del Rosario y San Bernardo. Santa Marta: Instituto de Investigaciones Marinas y Costeras "José Benito Vives de Andreis" - Invemar.
West, P. (2006). Conservation is our government now: the politics of ecology in New Guinea. Durham: Duke University Press.

Wilson, P. (2004). Las travesuras del cangrejo: un estudio de caso Caribe del conflicto entre reputación y respetabilidad. San Andrés: Universidad Nacional de Colombia, Sede Caribe.

Warrington, E., \& Milne, D. (2018). Governance. En G. Baldacchino (Ed.), The Routledge international handbook of island studies, a world of islands (pp. 173-201). New York : Routledge. 